\title{
Chronic Plasma Cell Deciduitis
}

National Cancer Institute

\section{Source}

National Cancer Institute. Chronic Plasma Cell Deciduitis. NCI Thesaurus. Code C118134.

The presence of decidual plasma cells, scattered or in aggregate. 